\title{
オソベツ川における吹雪による晶水増加と アイスジャム発生危険箇所の抽出に関する研究 STUDY ON SNOWSTORM-INDUCED INCREASES IN FRAZIL SLUSH AND THE IDENTIFICATION OF POTENTIAL ICE JAM LOCATIONS ON THE OSOBETSU RIVER
}

\author{
鳥谷部寿人 $1 \cdot$ 吉川泰弘 $2 \cdot$ 阿部孝章 $3 \cdot$ 黒田保孝 $4 \cdot$ \\ 船木淳悟 4 ・佐藤好茂 5 ・津村喜武 6 \\ Toshihito TOYABE, Yasuhiro YOSHIKAWA, Takaaki ABE, Yasutaka KURODA, \\ Jungo FUNAKI, Yoshishige SATO and Yoshitake TSUMURA \\ 1正会員 土木研究所 寒地土木研究所 道東支所( \\ 2正会員 博(工) 北見工業大学助教 社会環境工学科 ( $\bar{\top} 090-8507$ 北海道北見市公園町165番地) \\ 3正会員 博(工) 土木研究所 寒地土木研究所 寒地河川チーム(テ062-7602 北海道札幌市豊平区平岸1-3) \\ 4正会員 土木研究所 寒地土木研究所 寒地河川チーム( $\bar{\top} 062-7602$ 北海道札幌市豊平区平岸1-3) \\ 5 正会員 北海道開発局 帯広開発建設部帯広河川事務所 $(\bar{T} 089-0536$ 北海道中川郡幕別町札内西町73-6) \\ 6非会員＼cjkstart北海道開発局 釧路開発建設部 (广085-0017 北海道釧路町幸町10-3 釧路地方合同庁舎)
}

In December 2014, an ice jam occurred on the Osobetsu River after a snowstorm. This study investigated factors that contribute to increases in frazil slush and identified locations prone to ice jams. Previous studies using a hydraulic model experiment showed that an ice sheet's Froude number become small where ice sheets are static or accumulated. Moreover, a frazil slush calculation model that is based on the theory of heat balance in stream water accurately reproduced the measured thickness of frazil slush. However, no previous studies on ice jams have taken into account the Froude numbers of ice sheets. Also, certain weather phenomena, such as snowstorms and avalanches, are not factored into the current model for calculating frazil slush thickness. Therefore, the authors developed the model such as to take into account the effect of snowstorms. Furthermore, we used the Froude number of the ice sheet to identify potential ice jam locations on the Osobetsu River.

Key Words : Ice jam, Frazil slush, Calculation model, Ice- sheet's Froude number

\section{1. はじめに}

北海道の結水河川では，冬期において水板，晶水等の 流下によって引き起こされるアイスジャムの発生が報告 されている. この現象は，冬期間の水道用水や工業用水

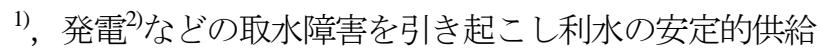
を劦か寸大きな社会的リスクとして懸念される。また， 2010年2月に渚滑川3)でもアイスジャムによる急激な水位 上昇が確認されており，近年みられる短時間に降る集中 豪雨や豪雪などの極端現象や温暖化による将来の気候変 動がもたらすリスクを考えると，その発生要因等を調査 ・分析し, 発生のメカニズムの解明, 発生防止対策や被 害軽減対策を立案する意義は大きい，なお，アイスジヤ
ムは国内固有の事象ではなく, 寒冷気候の諸外国では一 般的な事象である. ${ }^{4}$

アイスジャムには河川解水時の河水の破壊と流下に起 因するもの ${ }^{5}$ と, 河川結水初期の晶水の増加と流下に起 因するもの ${ }^{6}$ がある．2014年12月釧路川水系オソベッ川 において晶水の影響によるアイスジャムが発生した。 晶 水の増加と流下に起因するアイスジャム対策を実施する 上で，アイスジャムの発生危険箇所ならびにアイスジャ ムの材料となる晶水の発生条件に関寸る知見が重要であ る.アイイスジャムの発生条件》に関しては川幅，水深な らびに河床勾配に着目したアイスジャム水理実験があり， 水板が滞留または堆積する区間で水板のフルード数が小 さくなることを示している. 晶水の発生条件に関しては, 晶水発生計算モデル6゙により，北海道天塩川水系名寄川 


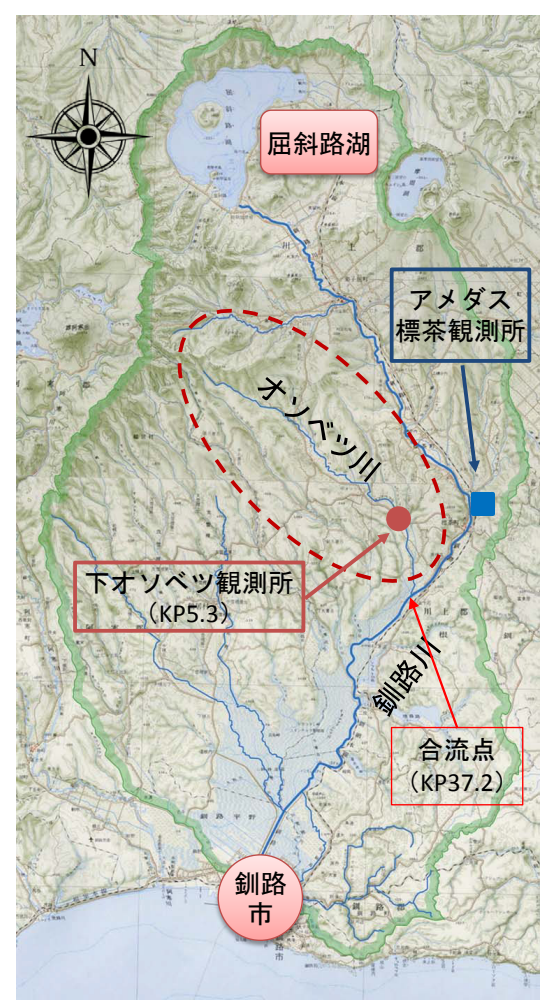

図-1 調査箇所図 $(1 / 50,000)$

真勲別頭首工における現地観測において良好な結果が得 られている. 一方で水板のフルード数を実際の河川に適 用した事例はなく, 晶水発生計算モデルでは暴風雪や雪 崩といった気象現象を考慮した研究は十分に実施されて いない.

本研究は，暴風雪に伴う晶水の増加によって発生した アイスジャム現象の解明を目的とする. 気象・水文デー タおよび現地調査を基に, 晶水発生計算モデルを用いて 晶水の発生要因を検討し, さらに氷板のフルード数を用 いてアイスジャムの発生危険箇所の抽出を試みた.

\section{2014年12月オソベツ川のアイスジャム}

\section{(1) 調査䇢所}

北海道東部を流れるオソベッ川は，図-1に示すとおり 一級河川釧路川(幹線流路延長 $154 \mathrm{~km}$, 流域面積 $\left.2,510 \mathrm{~km}^{2}\right)$ の一次支川である. 本川流路延長 $26.3 \mathrm{~km}$ ，流 域面積168.2km²であり, 釧路川KP37.2地点右岸で合流し ている. なお，釧路川のKP(キロポスト)は河口からの距 離 $(\mathrm{km})$ である.また，釧路川との合流点は釧路湿原内の 釧路川中流部に位置しており，河床勾配は釧路川合流点 付近で1/1200程度, 上流部で $1 / 200$ 程度である.

\section{（2）気象 $\cdot$ 水理}

アメダス標茶観測所の 1 時間当たりの降雪, 風向・風 速, 気温と下オソベツ観測所(KP5.3)の10分水位を図-2 に示寸．写真-1に下オソベツ観測所の状況を示寸．なお， オソベッ川のKPは釧路川合流点(KP37.2)からの距離 $(\mathrm{km})$ である. 釧路地方では発達した低気圧により記録的な暴

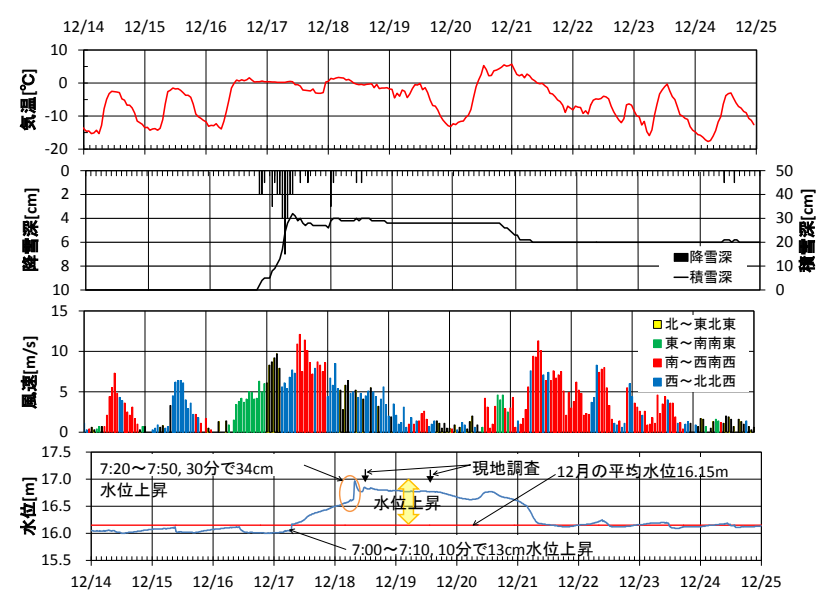

図-2 気象・水文(2014年12月14日から24日)

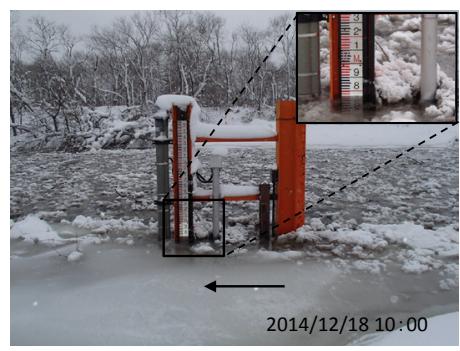

写真-1 下オソベツ観測所

風雪となりアメダス標茶観測所においてもその影響が観 測された．気温は12月14日から16日にかけて日周期を繰 り返しながらマイナスの值で推移していたが，低気圧の 通過に伴い，17日から18日にかけては一日を通してほぼ $0^{\circ} \mathrm{C}$ に近い值を示した. 降雪深ならびに積雪深は，16日 以前は0cmであったが，16日夜半から雪が降り始め17日 には日降雪深が32cmとなった。 この時期の風向は南か ら西南西の風が卓越しているが，17日から18日までの風 向は低気圧の移動に伴い、方角的には反時計回りに推移 した. 風速は 16 日午前中の平均で $2.0 \mathrm{~m} / \mathrm{s}$ 程度であったが, 17 日には日平均風速 $8.0 \mathrm{~m} / \mathrm{s} ， 18$ 日には日平均風速 $5.2 \mathrm{~m} / \mathrm{s}$ となっている。水位は14日0:00から17日7:00までは12月 の平均水位 $(\mathrm{H}=16.15 \mathrm{~m})$ 程度であったが，17日の7:00から 7:10までの 10 分間で $13 \mathrm{~cm}$ 上昇した. その後も水位の上昇 が続き，18日7:20に16.63mだった水位がピーク時の7:50 には $16.97 \mathrm{~m} に$ 達しており, この30分間で $34 \mathrm{~cm} の$ 急激な 水位上昇を記録した，なお，水位はいずれも暫定值であ る.

\section{（3）現地の状況}

図-3に調査箇所を示す。写真-2に下オソベツ橋 (KP3.0), 厚生橋(KP5.4)で上下流方向に撮影した写真を 示寸。なお，合流部(KP0.2) と恵橋(KP8.0)で河水は確認 されていない．また，いずれの調査箇所においても河道 を覆うような水板は確認されていない. 写真-2 (b) の下 オソベツ観測所における18日13時において水位 $(16.82 \mathrm{~m})$ はピーク時と比べて $15 \mathrm{~cm}$ 低下していた. 写真-2 (a)の18 日13時において下オソベツ橋(KP3.0), 写真-2 (b) の厚生 


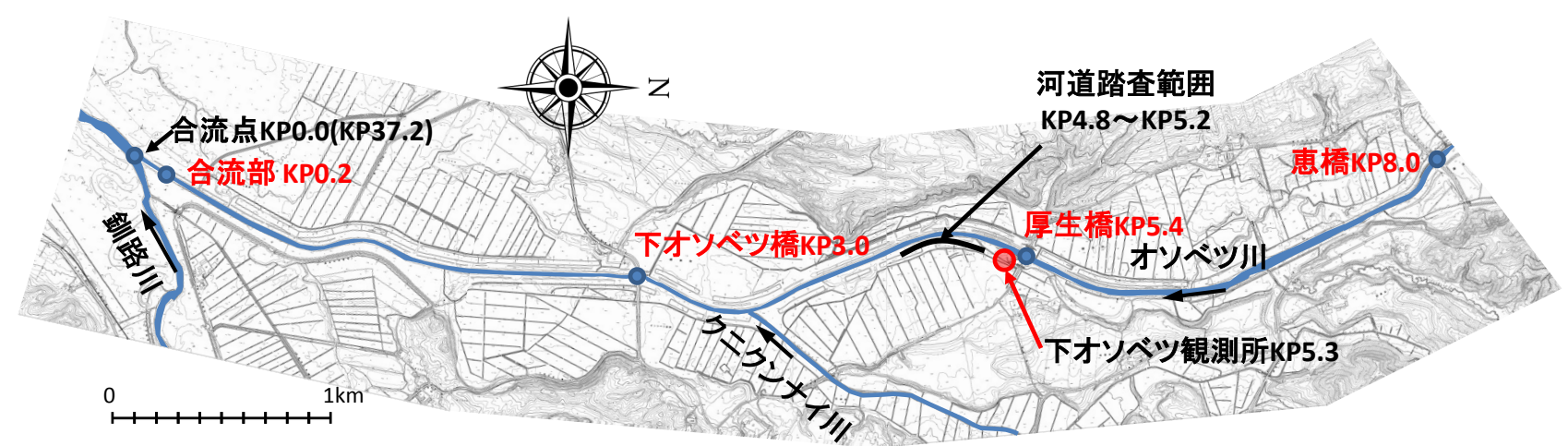

図-3 調査箇所 $(1 / 2,500)$

橋(KP5.4)の上下流方向に晶水が滞留している. 写真2(a)の19日15時において下オソベツ橋(KP3.0)では晶水 は確認されず，写真-2 (b) の厚生橋(KP5.4)上下流には晶 水が滞留し，橋の上流には開水面が広がっていた。

写真-3にKPごとの上下流方向の河道状況を示す. 18 日正午過ぎに下オソベッ観測所から下流方向に向かって 河道を調べた. KP5.2, KP5.0では上下流とも河水が河道 内に滞留あるいは堆積している状況が確認された。 また, 両河岸ともに樹木が繁茂しており，17日に大量に積もっ た雪の重みで樹幹が折れ，河道内に倒れこんでいる状況 が確認できた．また上流側に向けて撮影した画像には枝 に雪の痕跡がある一方で下流側に向けて撮影した画像に はないことから，降雪時は上流から下流に向かって強い 風が吹いていたと推察された，なお，KP4.8では上下流 とも河道内に河水は確認されなかった.

\section{3. アイスジャムの材料となる晶水の発生}

\section{（1）晶水発生計算モデル}

晶水発生計算モデルの゙は，以下の開水面における熱収 支と降雪の影響を考慮したモデルを用いた.

$$
\begin{gathered}
\frac{d h_{f}}{d t}=\frac{-\phi_{s}+\phi_{b}}{\rho_{i} L_{i}\left(1-\lambda_{f}\right)}+\frac{\phi_{e}+\phi_{c}}{\rho_{i} L_{i}\left(1-\lambda_{f}\right)}+ \\
\frac{\left(1-\lambda_{a}\right) d h_{a}}{\left(1-\lambda_{f}\right) d t}+\frac{\rho_{s}}{\rho_{i}\left(1-\lambda_{f}\right)} \frac{d h_{s}}{d t}+\frac{-\phi_{w}}{\rho_{i} L_{i}\left(1-\lambda_{f}\right)}
\end{gathered}
$$

$\rho_{i}\left[\mathrm{~kg} / \mathrm{m}^{3}\right]$ : 水の密度, $\rho_{s}\left[\mathrm{~kg} / \mathrm{m}^{3}\right]$ : 雪の密度, $\lambda_{a}$ [無次元］：アンカーアイスの空隙率， $\lambda_{f}$ [無次 元 $]$ : 晶水の空隙率, $t[\mathrm{sec}]$ : 時間, $L_{i}[\mathrm{~J} / \mathrm{kg}]$ : 水の 潜熱, $h[\mathrm{~m}]$ : 厚さ。添え字は各層の值であり，sは降 雪， $a$ はアンカーアイス， $f$ は河川内の晶水である. $\phi$ $\left[\mathrm{W} / \mathrm{m}^{2}\right]$ : 熱フラックスであり, $\phi_{s}$ : 短波放射量, $\phi_{b}$ : 長波放射量, $\phi_{e}$ : 潜熱フラックス, $\phi_{c}$ : 顕熱入 ラックス, $\phi_{w}$ : 流水から晶水への熱フラックスである. 各值の計算方法は既往文献) と同じにした。本計算モデ ルの入力值は, 気温, 風速, 日照時間, 降雪深, 河川の 水深, 河川の流速, 対象地点の緯度である.

\section{（2）吹雪による雪の供給について}

アメダス標茶観測所では 12 月 18 日の気温は $0^{\circ} \mathrm{C}$ 程度で, 日平均風速 $5.2 \mathrm{~m} / \mathrm{s}$ 觀測されている. さらに, 写真-1な

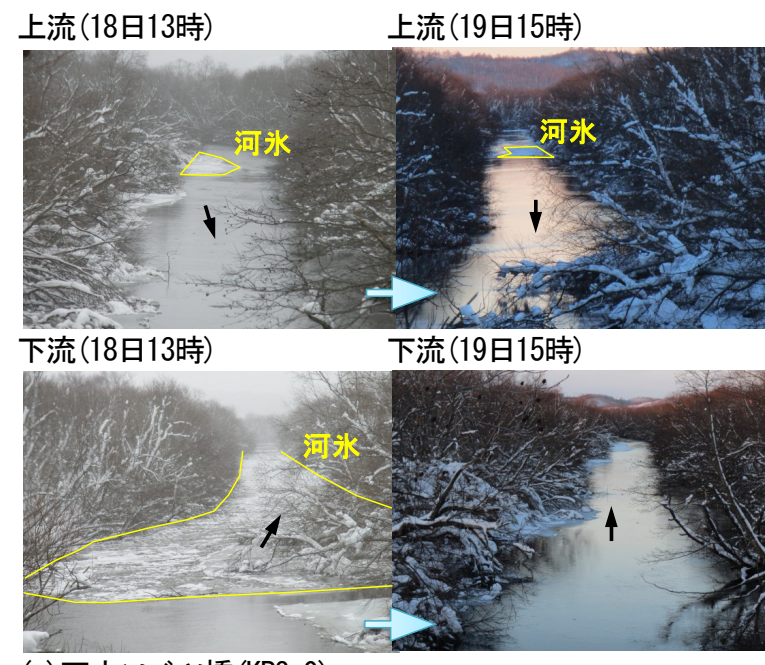

(a) 下オソベツ橋(KP3. 0)
上流(18日13時) 上流(19日15時)

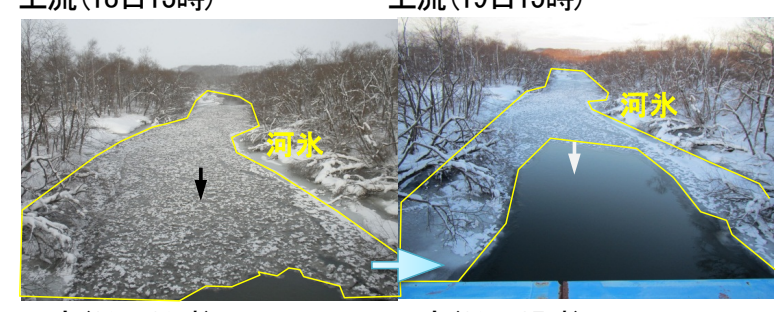

下流(18日13時)

下流(19日15時)

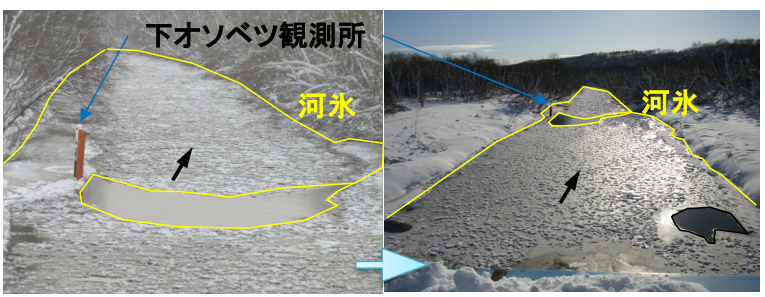

(b) 厚生橋 (KP5. 4)

\section{写真-2 河道の状況}

KP5. 2の上流側 12/18 12:20 KP5. 0の上流側 12/18 12:37 KP4.8の上流側 12/18 12:45

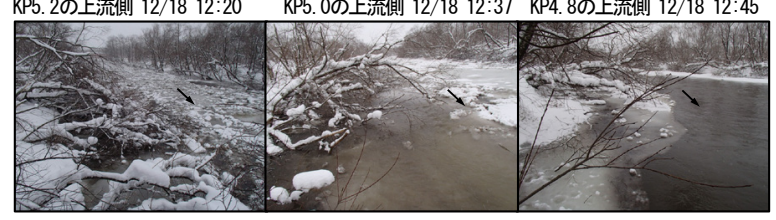

KP5. 2の下流側 12/18 12:20 KP5.0の下流側 12/18 12:37 KP4.8の下流側 12/18 12:45

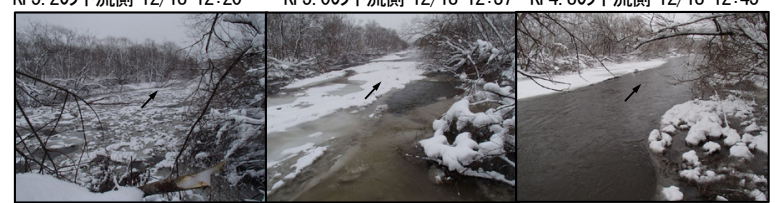

写真-3 河岸から見た河道内の状況(KP4. 8〜KP5. 2) 
表-1 吹雪の発生条件

\begin{tabular}{|l|l|l|l|l|l|}
\hline 条件 1 & $0>T>-5$ & かつ & $U_{7} \geqq 6.0$ & かつ & $S d \geqq 1 \mathrm{~cm}$ \\
\hline 条件 2 & $T \leqq-5$ & かつ & $U_{7} \geqq 5.0$ & かつ & $S d \geqq 1 \mathrm{~cm}$ \\
\hline 条件 3 & \multicolumn{5}{|c|}{$t \leqq 10 \mathrm{hr}$} \\
\hline
\end{tabular}

らびに写真-3から量水標や周辺の樹木に上流方向から吹 き込んだとみられる積雪が確認された。降雪以外にも吹 雪により雪が水面に運ばれた可能性が考えられる．本研 究では，吹雪による河川内一の晶水の供給現象について 晶水発生計算モデルに組み込んだ。松澤ら ${ }^{8}$ は観測から 得られた風速と吹雪量の経験式から飽和状態の吹雪量を 式(2)で示している.

$$
Q=0.005 U_{1.2}^{4}
$$

$Q[\mathrm{~g} / \mathrm{m} / \mathrm{s}]$ :吹雪量 , $U_{1.2}[\mathrm{~m} / \mathrm{s}]$ : 高さ $1.2 \mathrm{~m}$ の風速である. 吹雪量として供給される雪は降雪と積雪である. 風速が 速い場合でも，降雪や雪面からの雪が供給されなければ 吹雪は発生しない。吹雪の発生条件は竹内 ${ }^{9}$ による降雪 判別を伴う気温と風速による条件や武知ら ${ }^{10}$ による降雪 終了からの経過時間における条件があるが，ここでは気 象条件から表-1の判定に基づき，降雪有りの場合の条件 1,2かつ経過時間の条件3を満たす場合とした．表-1にお いて $T\left[{ }^{\circ} \mathrm{C}\right]$ : 気温, $U_{7}[\mathrm{~m} / \mathrm{s}]:$ 高さ7.0m風速, $S d:$ 積 雪深 $[\mathrm{cm}], t[\mathrm{hr}]$ : 降雪終了後の経過時間である. また, 風速分布は以下の対数則 ${ }^{11)}$ 用いた.

$$
U=\frac{u^{*}}{\kappa}\left(\ln \frac{z}{z_{0}}\right)
$$

$U[\mathrm{~m} / \mathrm{s}]$ : 風速, $u^{*}[\mathrm{~m} / \mathrm{s}]$ : 摩擦速度, $\kappa$ : カルマン定数 $(0.4)$ $z[\mathrm{~m}]$ : 高度, $z_{0}[\mathrm{~m}]$ : 粗度は周辺の土地利用状況より 畑・草地 $0.1 \sim 0.3$ の央值0.2として与えた. なお，風速 の鉛直分布は対数則に従うものとし， $u^{*}$ は風速の観測 值，観測高度と $z_{0}$ から求めた。

式(2)で得られた吹雪量 $Q$ を降雪相当に換算して晶水発 生計算モデルに組み込む手法を記す. 前提条件として, 吹雪によって運ばれる雪はすべて河道に供給されたと仮 定した．雪の密度について谷瀬ら ${ }^{12}$ は，積雪深計と積雪 重量計を用いた雪の密度の観測を行い，雪の密度は降雪 後の気温変化や圧密に伴い時間と共に変化することを観 測しており, 観測結果から降雪直後の雪の密度は $100 \mathrm{~kg} / \mathrm{m}^{3}$ 程度の結果を得ている。例えば吹雪量 $Q=1 \mathrm{~g} / \mathrm{m} / \mathrm{s}$ の場合, 10 分間の累計吹雪量は $0.6 \mathrm{~kg} / \mathrm{m}$ であり， 雪の密度を $100 \mathrm{~kg} / \mathrm{m}^{3}$ として体積に置き換えると雪の体 積は $0.006 \mathrm{~m}^{3} / \mathrm{m}$ となる. これを $\mathrm{cm}$ 単位にして高さの次元 で表すと $0.6 \mathrm{~cm}$ となる. このようにして10分累計吹雪高 $H_{s}[\mathrm{~cm}]$ を求めた。 なお，(2)式は樹木の無い場合におけ る経験式であるため，河畔林による吹雪の捕捉は考慮さ れていない. 本研究では枝に残された雪の痕跡から卓越 した風は上流からであり，河畔林による影響は少ないと 考えた．なお，定量的な評価を行う場合は別途，現地観 測あるいは実験等により捕捉率を考慮する必要がある.

（3）アイスジャム発生時の晶水の増加
本計算モデルを用いてアイスジャム発生時の晶水の発 生量を推定した. 計算モデルの気象データ入力値は, ア メダス標茶観測所の值を用いた．気温・風速は 10 分ごと の值とし， 日照時間は1時間ごとの值を10分ごとの值と した．降雪深は，1時間ごとの值を10分単位で等分した 值と, 式(2)から求められた10分累計吹雪量 $Q$ を基に計算 した10分累計吹雪高 $H_{s}$ を加えた值とした. 水理データは 12月3日，11日，22日に下オソベツ観測所で行なった定 期流量観測值を用いた。 この值を平均して断面平均流速 0.573[m/s], 断面平均水深 $0.303[\mathrm{~m}]$ を入力值とした. 対象 地点の緯度としてアメダス標茶観測所の緯度(北緯 $\left.43.30^{\circ}\right)$ を与えた。 なお，アンカーアイスは水温が $0^{\circ} \mathrm{C}$ 以 下の過冷却状態において最低気温約 $-10^{\circ} \mathrm{C}$ 以下の時に発 生する ${ }^{13)}$ とされており，今回は低気圧の通過に伴い，気 温がアイスジャム発生前では， $0^{\circ} \mathrm{C}$ 付近であったことか らアンカーアイスは発生していないと仮定して無視した。

平成26年12月14日0:10からの晶水発生計算モデルによ る発生晶水厚の計算結果を図-4に示寸. 図中に吹雪量を 考慮した場合としない場合の発生晶水厚と降雪深の計算 結果ならびに水位上昇期間を示した. 水位上昇期間は平 成26年12月の平均水位 $(16.15 \mathrm{~m})$ より水位が高い期間とし た. 下オソベツ観測所の水位は12月17日7:00から上昇し 始め，12月18日7:50にピークを迎えている.

この24時間の晶水厚の積算值と水位上昇する前の24時 間の值と比較した。吹雪量を考慮しない場合，水位上昇 前の晶水厚の積算值は $3.5 \mathrm{~cm}$ であり, 水位上昇時の值も $3.2 \mathrm{~cm}$ でその差はほとんどない，一方で吹雪量を考慮し た場合，水位上昇前の積算值は $3.6 \mathrm{~cm}$ であり，水位上昇 時の值は $14.8 \mathrm{~cm}$ で差が生じた. アイスジャム発生期間に 関して吹雪量を考慮した方が，晶水厚は大きくなる結果 を得た。

次に，水位上昇と発生晶水厚の関係を図-5に示寸，吹 雪量を考慮しない場合，水位上昇の時期に遅れて発生晶 氷量が増加していた。一方で吹雪量を考慮したことで水 位上昇と発生晶水厚が増加する時期がおおむね一致した。 現地観測および数值計算の検討結果から，陸域に積もっ た雪の一部が吹雪によって多量に河川几供給され，晶水 が増加しアイスジャムが発生したと推察された。

\section{4. アイスジャムの発生危険箇所の抽出}

\section{（1）河水のフルード数}

既往研究6)では，アイスジャム発生条件について，ア イスジャム発生時の水理量を用いた水理実験を行い，水 板のフルード数を用いてアイスジャム発生の可能性を評 価している. 水板のフルード数は分母における代表長と して河水厚を取った值であり，小さくなると水板の速度 が減衰して滞留しやすくなることを意味する. 晶水が大 量に発生した場合、水板と同様に塊となって流下寸るこ 


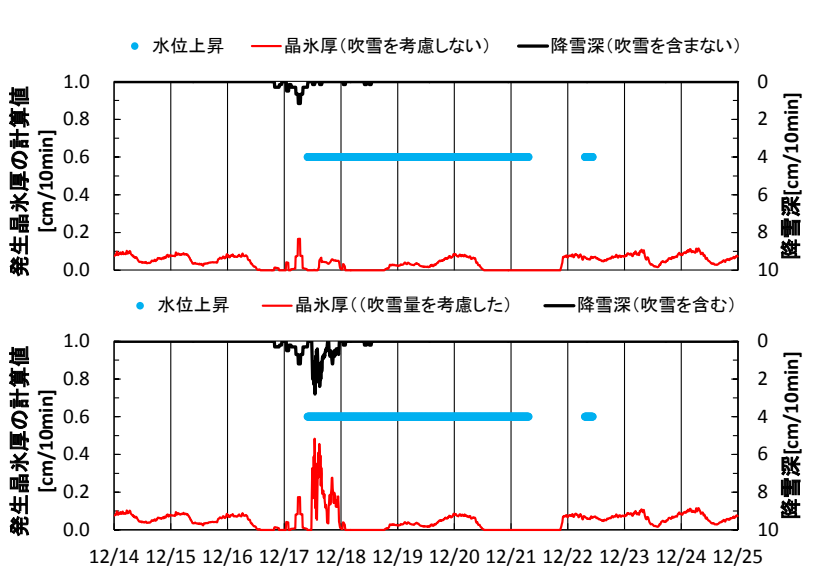

図-4 晶水発生計算モデルによる計算結果
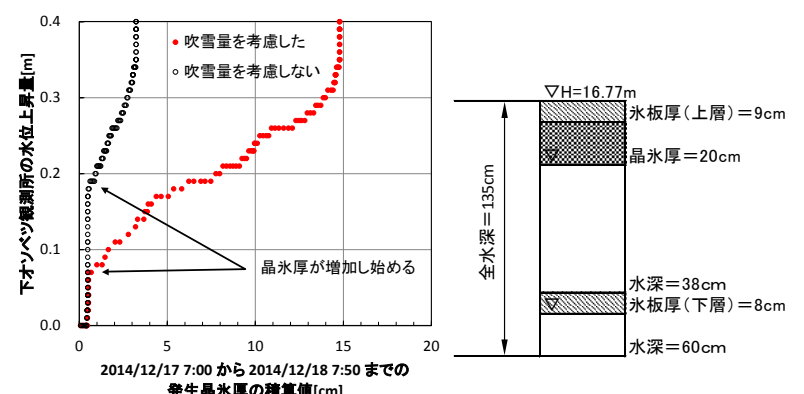

図-5 発生晶水厚の積算値と水位

図-6 河水の断面図

とから, 本研究では水板のフルード数を試験的に適用し, 河水のフルード数と呼称する. 検討区間は急激な水位上 昇が発生した下オソベツ観測所を含むKP1.0からKP5.4と した. 河水のフルード数を以下に示す.

$$
\begin{gathered}
F r_{i}=\frac{u_{i}}{\sqrt{\Delta \epsilon g h_{f}}} \\
\Delta \epsilon=\frac{\left(\rho_{w}-\rho_{i}\right)}{\rho_{w}}
\end{gathered}
$$

$F r_{i}$ [無次元] : 河水のフルード数, $u_{i}[\mathrm{~m} / \mathrm{s}]$ : アイスジャ 么発生直前の河水の速度, $g$ : 重力加速度 $\left[\mathrm{m} / \mathrm{s}^{2}\right]$, $h_{f}[\mathrm{~m}]$ : 河水厚, $\rho_{w}\left[\mathrm{~kg} / \mathrm{m}^{3}\right]$ : 水の密度 $1000 \mathrm{~kg} / \mathrm{m}^{3}$, $\rho_{i}\left[\mathrm{~kg} / \mathrm{m}^{3}\right]$ : 水の密度 $917 \mathrm{~kg} / \mathrm{m}^{3}$ である.

河水のフルード数 $F r_{i}$ を求めるには，河水の厚さ $h_{i}$ と アイスジャム発生直前の河水の速度 $u_{i}$ を求める必要があ る. 以下に具体的な計算条件を明記する.

\section{a) 河水厚 $h_{f}$}

下オソベツ観測所周辺における12月19日12時の河水厚 の観測值を図-6に示す。図より河水厚 $h_{f}$ は上層が $29 \mathrm{~cm}$, 下層が $8 \mathrm{~cm}$ である. なお，上層の河水厚 $h_{f}$ は水板と晶水 を足した值であり，上層と下層を合わせると河水厚 $h_{f}=$ $0.37 \mathrm{~m}$, 河水断面積 $A_{i}=8.88 \mathrm{~m}^{2}$ である.

縦断的な河水厚 $h_{f}$ は, $h_{f}=A_{i} / B_{w}$ (水面幅)として求め た. $A_{i}$ は一定值を与え, $B_{w}$ は後述するiRICソフトウエ アで不等流計算を行い算出した。 図-7に水面幅 $B_{w}$ およ び河水厚 $h_{f}$ の縦断変化を示寸.

b）アイスジャム発生直前の河水の速度 $u_{i}$

アイスジャム発生直前の河水は, 流水と共に流下して
おり，河川の流速に等しいと仮定した。流速の計算は iRICソフトウエア1次元計算モデルCERI 1D ${ }^{14)}$ を用いた. オソベッ川の横断測量(1997年～2000年，世界測地変換) はKP間(200mピッチ)で行われており，水面幅(20m〜 $30 \mathrm{~m})$ と比べると約10倍である. 解析するうえで縦断的な 横断測線間隔を水面幅程度で与えることが望ましいと考

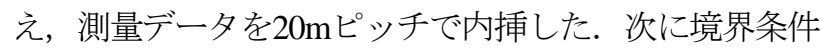
である流入量, 下流端水位および粗度係数の設定方法を 記す。下オソベツ観測所の時刻流量月表より12月の観測 流量は12:00のみ記録されている.はじめに12月16日12:00 の流入量 $\left(4.21 \mathrm{~m}^{3} / \mathrm{s}\right)$ と下流端水位は釧路川合流点の 16 日の 毎時平均水位 $12.09 \mathrm{~m}$ を境界条件として与えて再現計算を 行った. 下オソベツ観測所12:00の水位(16.03m) と計算水 位(16.00m)がほぼ等しくなる粗度係数(0.03)を得た. アイ スジャム発生直前の河水の速度 $u_{i}$ を推定するため, 発生 1時間前の12月17日6:00の下オソベツ観測水位 $(16.05 \mathrm{~m})$ と 等しくなるように流入量を $5.21 \mathrm{~m}^{3} / \mathrm{s}$ に設定し，下流端水 位は釧路川合流点の17日の毎時平均水位12.11mを与えて 計算した. 結果を図-8に示す.

c）川幅縮小比 $\hat{\lambda}$

既往研究 ${ }^{15)}$ では, 河道狭窄部がアイスジャム発生現象

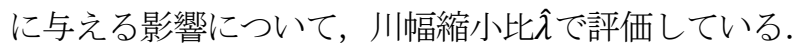

図-9に川幅の模式図を示し，川幅縮小比令は以下となる.

$$
\hat{\lambda}=\frac{\lambda_{1} \cdot B_{2}+\lambda_{0}\left(B_{1}-B_{2}\right)}{B_{1}}=\frac{B_{2}}{B_{1}}
$$

$\lambda$ [無次元] : 河水の速度の減衰割合, $\lambda_{0}=0, \lambda_{1}=1, B_{1}$ : 上流の川幅, $B_{2}$ : 下流の川幅を表す. なお, 川幅縮小比 人の影響を受けるのは上流の断面(1-1)である. 結果を図一 10に示す.

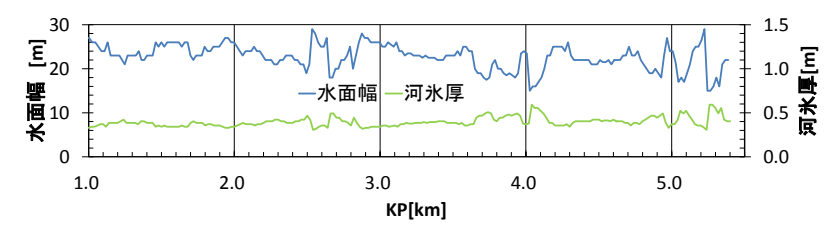

図-7 河水厚 $h_{f}$ と水面幅 $B_{w}$ の縦断変化

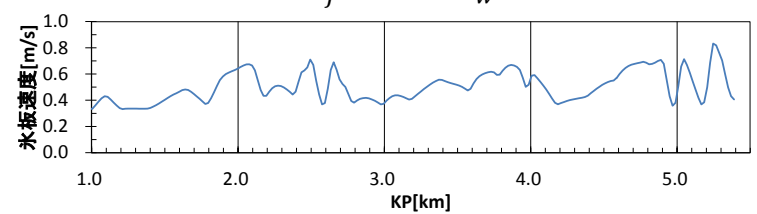

図-8 アイスジャム発生直前の河水の速度 $u_{i}$ の縦断変化

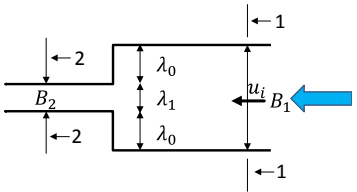

図-9 川幅縮小比 $\hat{\lambda}$ 考え方

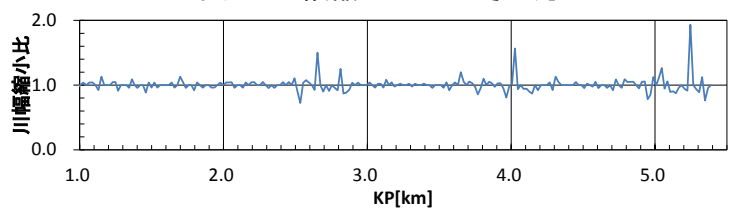

図-10 川幅縮小比 $\hat{\lambda}$ の縦断変化 


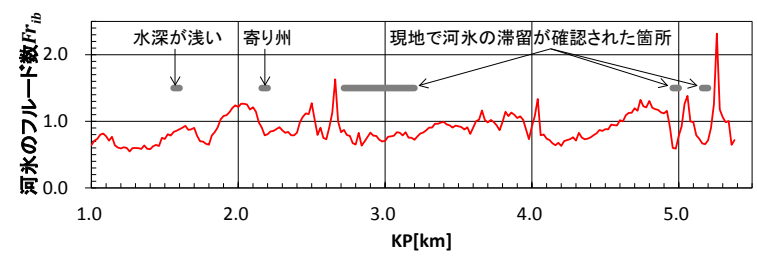

図-11「川幅の影響を考慮した河氷のフルド 数」Fr $r_{i b}$ の縱断変化

$\left(F r_{i b}\right.$ が小さいほどアイスジャム発生の危険性が高くなる）

\section{（2）アイスジャムの発生危険箇所}

本研究では実河川におけるアイスジャム発生危険箇所 を抽出する值として以下の「川幅の影響を考慮した河水 のフルード数」 $F r_{i b}$ [無次元]を提案する.

$$
F r_{i b}=F r_{i} \hat{\lambda}
$$

$F r_{i b}$ の縦断的な変化を図-11に示す. 図-11より, KP1.0 $\sim \mathrm{KP} 1.8, \quad \mathrm{KP} 2.2 \sim \mathrm{KP} 2.4, \mathrm{KP} 2.6, \mathrm{KP} 2.8 \sim \mathrm{KP} 3.2, \mathrm{KP} 4.1$ 〜KP4.5, KP5.0, KP5.2でFr $r_{i b}$ の小さい箇所が見られた. このうち, KP2.7〜 KP3.2, KP5.0, KP5.2は現地で河水の 滞留が確認された箇所に相当する．2015年9月25日に横 断測量を行ったところ，水深が浅い所(KP1.6)や寄り州 が発達して一部陸化している箇所(KP2.2)が確認された. 図-9は河道を模式的に簡素化したものであるが，冬期間 の渇水時には一部で急縮箘所がみられ，これも河水の流 下の阻害要因と考えられた。また，河岸に樹木が密に繁 茂し，樹幹が河道内に倒れ込む状況も見られた。このよ うに河積が狭まっている所に，樹木が倒れこみ，河水の 流下をいっそう阻害していた可能性も伺われた。

\section{5. まとめ}

2014年12月18日に北海道東部に位置するオソベツ川で 発生したアイスジャムにおいて, 気象・水理データおよ び現地調査に基づきその発生要因について整理・分析し た結果，以下のことが明らかとなった.

1)記録的な豪雪と強風を伴う低気圧によって発生した吹 雪により，河道に運ばれた雪を晶水発生計算モデルに 取り込むことで、発生晶水厚の増加と水位上昇の関係 を明らにした。このことは，雪由来の晶水が多量に発 生することで, 流水の流下が妨げられ，アイスジャム 発生のリスクが高まることを意味している.

2)「川幅の影響を考慮した河水のフルード数」Fr $r_{i b}$ を用 いてアイスジャム発生危険箇所の抽出を試みた結果，河 水が滞留, 堆積した区間で $F r_{i b}$ が減少していることが示 され，実際の河川においてもFr $r_{i b}$ を指標としてアイス ジャム発生危険箇所を予見できることが示唆された.

この現象は河川管理や取水施設等に影響を及ぼすもの であり，近年の異常気象等によって引き起こされるリス クの一つと考えられる. 得られた知見は，アイスジャム の発生防止対策や被害軽減対策に適用可能な技術であり， さらに事象を集めて研究を進めていく必要がある.
謝辞 : 寒地土木研究所雪水チーム松澤勝博士には吹雪の 発生現象について助言を頂いた. (株北開水工コンサルタ ント釧路支店ならびに寒地土木研究所道東支所鶴澤利樹 氏には現地調査に協力して頂いた，査読者の方には拙稿 の改良に有益な助言を頂いた，記して謝意を表します.

\section{参考文献}

1) 入交泰文, 吉川泰弘, 黒田保孝 : 天塩川水系名寄川真勲別頭 首工における晶水の発生について, 第58回(平成26年度)北海 道開発技術研究発表会, 2015.

2) 伊藤丹, 吉川泰弘, 黒田保孝, 村瀬竜也 : 2013 年4 月に $\mathrm{A}$ ダムで発生したアイスジャムによる取水障害, 土木学会北海 道支部論文報告集，第70号，2013．

3) 吉川泰弘, 渡邊康玄, 早川博, 平井康幸 : 渚滑川のアイス ジャムに関する現地観測, 寒地土木研究所月報, №701, pp. 2-9, 2011.

4) Shahramanjan M. A. : Ice Jams forecast and technologies of their destruction on the rivers of the Russian Federation, International Association of Hydraulic Engineering and Research, International Symposium on Ice, $17^{\text {th }}$, pp.XXV II-XL II, 2004.

5）吉川泰弘, 渡邊康玄, 早川博, 平井康幸 : 河川解水時の河水 の破壊と流下に関する研究, 水工学論文集, 第55巻, pp. S_1075-S_1080, 2011.

6) 吉川泰弘, 黒田保孝, 橋場雅弘, 入交泰文 : 寒冷地河川におけ る晶水発生計算モデルの開発と取水障害の発生条件, 水工学 論文集，Vol.59，pp. I_1327-1332，2015.

7）吉川泰弘, 黒田保孝, 伊藤丹, 渡邊康玄 : 結水河川における 河道形状を考慮したアイスジャム発生条件に関する研究, 河 川技術論文集第20巻, pp. 241-246, 2014.

8) 松澤勝, 金子学, 伊東靖彦, 上田真代, 武知洋太 : 風速と吹 雪量の経験式の適用に関する一考察，第26回寒地技術シンポ ジウム, pp.45-48, 2010.

9)竹内政夫 : 降雪時の高い地吹雪の発生臨界風速, 昭和61年度 日本雪水学会全国大会予稿集, pp.252, 1986.

10) 武知洋太, 中村浩, 松澤勝, 川中敏朗 : 地吹雪発生時の気 象条件に関する一考察, 雪水研究大会講演要旨集 2010(0), 216-216, 2010.

11) 近藤純正ホームページ, URL: http://www.asahi- net.or.jp/ $\sim r k 7 j-k n d u / k e n k y u / k e 01 . h t m l($ 参照日2015年7月2日)

12) 谷瀬敦, 山下彰司 : 積雪重量計を用いた積雪層の観測につ いて, 水工学論文集, 第51巻, pp.355-pp.360, 2007.

13) 清原正道 : アンカーアイスの形態と発生条件について_第 11回寒地技術シンポジウム, pp.159-pp.163, 1995.

14) 河川シミュレーションソフトiRIC，URL:http.//iric.org/ja/(参 照日2015年5月26日)

15) 北島笙子, 吉川泰弘, 黒田保孝 : 河道狭窄部がアイスジャ ム発生条件に与える影響, 土木学会北海道支部論文報告集, 第71号, 2014. 